\title{
Heteronormativitas, Wacana LGBT dan Perjuangan Komunitas Waria Melawan Stigma1
}

\author{
Inestya Kartikaningdryani ${ }^{2}$
}

\begin{abstract}
Abstraksi
Kelompok LGBT sering mendapat diskriminasi dan kekerasan karena mereka dianggap melanggar nilai-nilai heteronormativitas. Waria yang termasuk dalam kelompok $\mathrm{T}$ (Transgender) merupakan kelompok paling rentan menerima kekerasan karena penampilan fisik mereka yang lebih kentara dibanding kelompok LGB. Ketidakselarasan tubuh dan perilaku ini membuat waria dianggap aneh dan tereksklusi dari masyarakat melalui konstruksi stigmatisasi yang bersifat homophobia. Kondisi marginalisasi ini mendorong mereka hidup di jalanan dan membentuk sebuah komunitas alternatif. Di Yogyakarta, tantangan bagi komunitas waria tidak serta merta melawan diskriminasi dan kekerasan. Pada 2014, Pemprov DIY mengesahkan Peraturan Daerah (Perda) tentang penanganan gelandangan dan pengemis. Kondisi ini mebuat perjuangan komunitas waria tidak hanya soal memperjuangkan identitas mereka, melainkan juga resistensi politik. Lebih dari itu, keberadaan perda ini dan aksi vigilantisme yang dilakukan kelompok intoleran mendorong adanya perubahan strategi gerakan komunitas waria. Sayangnya, perubahan ini tidak mendapat sambutan positif dari semua waria.
\end{abstract}

Kata kunci: LGBT, heteronormativitas, gerakan sosial, identitas gender, stigmatisasi, homophobia

\begin{abstract}
LGBT people often face discrimination and violence because they are considered to violate heteronormativity values. Transgender people who are included in the $\mathrm{T}$ group (Transgender/ Transvestites) are the most vulnerable groups to receive violence because their physical appearance is more obvious compare to LGB groups. Such bodily disharmony and behavior make transvestites considered as strange and thus excluded from society through the construction of homophobic stigmatization. This marginalization encourages them to live on the streets and form alternative community. In Yogyakarta, the challenge for the waria community is not necessarily against discrimination and violence. In 2014, the Provincial Government of Yogyakarta passed a Regional Regulation (Perda) on handling homeless people and beggars. The regulation has affected the struggle of the waria community not only for accepting their identity, indeed for political resistence. Moreover, the existence of this regional regulation and the action of vigilantism by intolerant groups have led the waria to cope with the strategy of the transgender community movement. Unfortunately, such transformation did not always receive support from all transgenders.
\end{abstract}

Keywords: LGBT, heteronormativity, social movements, gender identity, stigmatization, homophobia

\section{A. Latar Belakang}

Berangkat dari data UNESCO tahun 2012, bullying terhadap Lesbian, Gay, Bisexual and Transgender (LGBT) menempati peringkat tertinggi nomor 2 setelah bullying berat badan (Oetomoe dan Suvianita, 2013). Di Indonesia, survey yang dilakukan oleh kolaborasi Arus Pelangi, Komunitas
Sehati Makassar (KSM) dan People Like Us Satu Hati Yogyakarta (PLUSH) menemukan 89,3\% temanteman LGBT pernah mengalami kekerasan (Laazulva, 2013). Bisa jadi hal ini disebabkan oleh pemikiran biner yang digunakan oleh sebagian besar masyarakat khususnya di Indonesia dalam memandang isu LGBT. Baik pemikiran biner maupun essensialism, hanya mengakui adanya laki-

\footnotetext{
${ }^{1}$ Untuk kutipan atau sitasi artikel ini: Kartikaningdryani, Inestya. 2019. "Heteronormativitas, Wacana LGBT dan

Perjuangan Waria Melawan Stigma”. Jurnal Pemikiran Sosiologi Vol 6(2): 191-209

2 Media Analyst, Indonesia Indikator. Kontak: i.kartikaningdryani@gmail.com
} 
Jurnal Pemikiran Sosiologi Volume 6 No.2 2019

Heteronormativitas, Wacana LGBT dan Perjuangan Komunitas Waria Melawan Stigma

Inestya Kartikaningdryani

laki dan perempuan. Serta, mengidentifikasikan laki-laki harus bergaya maskulin dan perempuan bergaya feminin. Sehingga, orang-orang yang berada di luar "jalur" ini dianggap sebagai orang-orang yang tidak normal.

Dengan stigma negatif sebagai orang-orang abnormal dan pendosa tersebut membuat temanteman LGBT sering kali mendapatkan perlakuan diskriminasi, bahkan di dalam intitusi terkecil dalam masyarakat yaitu keluarga. Berdasarkan laporan United Nations Development Programs (UNDP) pada 2014 dalam Being LGBT in Asia: Indonesia Country Report, setidaknya ada dua faktor yang menyebabkan LGBT memilih untuk meninggalkan keluarganya (Oetomoe dan Suvianita, 2013). Pertama, desakan yang besar untuk menikah secara heteroseksual dan mendirikan keluarga. Biasanya, pernikahan hanya sebagai kedok agar mereka fit di dalam struktur masyarakat dan dengan harapan bahwa menikah secara heteroseksual dapat 'menyembuhkan' mereka. Kedua, kepercayaan terhadap agama di kalangan masyarakat Indonesia. Sebagai penduduk Muslim terbesar di dunia, masyarakat Indonesia masih memegang teguh ajaran-ajaran agama. Karena di dalam kitab-kitab sebagian besar agama, hanya orientasi seksual dan sikap heteroseksual saja yang diakui.

Selain di lingkungan keluarga, perlakuan diskriminasi yang sering ditujukan kepada LGBT adalah kesempatan untuk mendapatkan pekerjaan yang layak. Undang-undang (UU) Tenaga Kerja Nomor 13/2003 dengan tegas melarang segala bentuk diskriminasi ("UU Nomor 13/2003 Ketenagakerjaan," n.d.). UU tersebut tidak menyebutkan bahwa identitas gender atau orientasi seksual bisa menjadi dasar untuk mendiskriminasi pekerja.

Penelitian ini tidak lepas dari memanasnya isu mengenai LGBT pada 2016 lalu. Berawal dari tajuk utama berita tanah air yang ramai memberitakan sebuah organisasi mahasiswa kampus yang diduga sebagai sebuah komunitas LGBT. Adalah Support Group and Research Center on Sexuality Studies (SGRC) UI, sebuah organisasi mahasiswa di Universitas Indonesia yang memang sering mengadakan kegiatan seperti diskusi dan menyediakan layanan konseling seputar masalah seksualitas bagi remaja (Sindonews, 2016; CNN Indonesia, 2016; Tempo, 2016). Organisasi mahasiswa ini diisukan sebagai komunitas LGBT di lingkungan kampus karena mengadakan kegiatan yang diberi nama "LGBT Peer Support Network" dan bekerjasama dengan Melela.org. Melela.org sendiri merupakan sebuah situs dimana orang-orang LGBT bisa mencurahkan ceritanya sekaligus untuk mengedukasi masyarakat umum terkait LGBT (CNN Indonesia, 2016).

Kondisi ini diperparah oleh pernyataanpernyataan diskriminatif yang dikeluarkan negara melalui pejabat-pejabat publiknya. Salah satunya, Menteri Riset, Teknologi dan Pendidikan Tinggi (Menristekdikti), Mohammad Nasir, sempat mendapat kecaman dari beberapa kelompok pro LGBT terkait pernyataannya menanggapi keberadaan SGRC UI yang dianggap sebagai komunitas LGBT di wilayah kampus. Mohammad Nasir melarang komunitas LGBT memasuki wilayah kampus, di mana hal itu dianggap sebagai ancaman bagi moral bangsa dan kampus sebagai penjaga moral harus bisa menjaga nilai-nilai moral dan luhur 
Jurnal Pemikiran Sosiologi Volume 6 No.2 2019

Heteronormativitas, Wacana LGBT dan Perjuangan Komunitas Waria Melawan Stigma

Inestya Kartikaningdryani

bangsa Indonesia (CNN Indonesia, 2016; Detik News, 2016). Meskipun dirinya sudah mengklarifikasi mengenai larangan yang dimaksudkan adalah aktivitas seperti bercinta dan bermesraan di dalam kampus, tetapi bagi beberapa orang hal ini dianggap konyol karena kapasitasnya sebagai Menristekdikti, Mohammad Nasir tidak berwenang untuk mengatur hak preferensi seksual seseorang (Beritagar.id, 2016). Dalam laporannya yang berjudul "Permainan Politik ini Telah Merusak Hidup Kami: Komunitas LGBT Indonesia Berada Dibawah Ancaman" pada tahun 2016, peneliti Human Rights Watch (HRW), Kyle Knight (2016) mengatakan bahwa pernyataan-pernyataan diskriminatif dari pejabat publik ini menjadi semacam legitimasi bagi kelompok fundamentalis untuk melakukan aksi kekerasan dan diskriminasi terhadap kelompok LGBT.

Di Yogyakarta, The Wahid Institute mencatat ada 39 kasus kekerasan terjadi dalam kurun waktu antara 2014 hingga 2016 (Ahnaf dan Salim, 2017). Kondisi ini membuat Yogyakarta menjadi daerah dengan tingkat kekerasan atau pelanggaran kebebasan beragama dan berkeyakinan tertinggi kedua setelah Jawa Barat (The Wahid Institute, 2014 dalam Ahnaf dan Salim, 2017). Menariknya, pola aksi kekerasan yang dilakukan oleh kelompok fundamentalis di Yogyakarta berbeda dengan kelompok fundamentalis di daerah lain. Terdapat dua aktor utama dalam setiap aksi kekerasan terhadap kelompok minoritas di Yogyakarta, yakni Forum Ukhuwah Islam (FUI) dan Front Jihad Islam (FJI). Kedua kelompok tersebut menghindari tuduhan bagian dari jaringan terorisme internasional. Mereka tidak memasukkan negara
Islam atau khilafah sebagai agenda dan isu politiknya (Ahnaf dan Ismail, 2017). Tempat-tempat yang diduga menyebar kemaksiatan tidak tersentuh oleh aksi mereka. Justru kelompok-kelompok minoritas seperti kelompok LGBT, Kristen, Syiah, Ahmadiyah dan komunisme-lah yang menjadi sasaran mereka karena dianggap sebagai ancaman bagi keutuhan bangsa dan negara.

Salah satu contohnya adalah penutupan Pondok Pesantren Waria Al Fattah yang dilakukan FJI. Dalam wawancaranya dengan Rappler, Ibu Shinta Ratri selaku pemimpin pondok pesantren ini menjelaskan penutupan pondok pesantren yang dipimpinnya berawal dari hoaks yang disebarkan oleh portal berita Panjimas.com (Rappler, 2016). Portal berita tersebut menyebutkan adanya fiqh waria yang digunakan dalam proses pembelajaran pondok pesantren. Hal inilah yang kemudian memicu FJI menutup Pondok Pesantren Waria Al Fattah pada Jumat, 19 Februari 2016.

Masalah-masalah ini sebenarnya muncul dari hal yang paling dekat dengan manusia, yakni seksualitas. Seksualitas adalah nama yang diberikan pada sebuah konstruksi sejarah bukan realitas tersembunyi yang susah untuk dipahami, tetapi merupakan sebuah jaringan luas yang tampak jelas di mana stimulasi atas tubuh, intesifikasi kenikmatan, pembentukan pengetahuan tertentu, penguatan terhadap kontrol dan resistensi, dikaitkan antara satu dengan yang lainnya (Foucault, 1998:105-106 dalam Setyorini, 2011). Hal ini dipertegas dengan gagasan Judith Butler bahwa menggambarkan realness atau kebenaran tentang gender dan seksualitas diproduksi dan direproduksi melalui serangkaian tindakan, gesture 
Jurnal Pemikiran Sosiologi Volume 6 No.2 2019

Heteronormativitas, Wacana LGBT dan Perjuangan Komunitas Waria Melawan Stigma

Inestya Kartikaningdryani

dan hasrat yang mengimplikasikan identitas gender paling essensial (1990, dalam Setyorini, 2011).

Setyorini (2011) mengatakan gender adalah sebuah proses imitasi dan pengulangan performativitas yang tidak berhenti. Bisa jadi lakilaki yang diharuskan bergaya maskulin merupakan imitasi dari anggapan-anggapan tradisional yang terkonstruk dan menjadi nilai dari menjadi seorang laki-laki. Dengan kata lain, tidak ada keaslian dari menjadi seorang maskulin atau feminin, karena itu hanyalah nilai-nilai yang terus terulang selama bertahun-tahun sehingga menjadi laki-laki yang maskulin dan perempuan feminin menjadi sesuatu yang dianggap alamiah. Hal ini juga berlaku untuk heteroseksual, nilai-nilai di mana hanya ada laki-laki dan perempuan yang jatuh cinta itu dianggap sebagai sesuatu yang alamiah. Sebagai konsekuensinya, sering kali orang-orang homoseksualitas dianggap abnormal karena mereka keluar dari konstruksi gender dan seksualitas yang diwacanakan melalui nilai budaya dan agama serta diperkuat oleh kebijakan negara menghasilkan stigmatisasi manusia atau kelompok lain yang berbeda dari yang umum dan dianggap normal (Yuliani, 2006 dalam Laazulva, 2013).

Bisa jadi, stigma negatif terhadap temanteman LGBT muncul karena kurangnya pemahaman masyarakat mengenai sexual orientation, gender expression, and gender identity (SOGIE). Killerman (2011, dalam Laazulva 2013) memberikan pengertian mengenai SOGIE melalui skema The Gender Beard Person sebagai berikut:
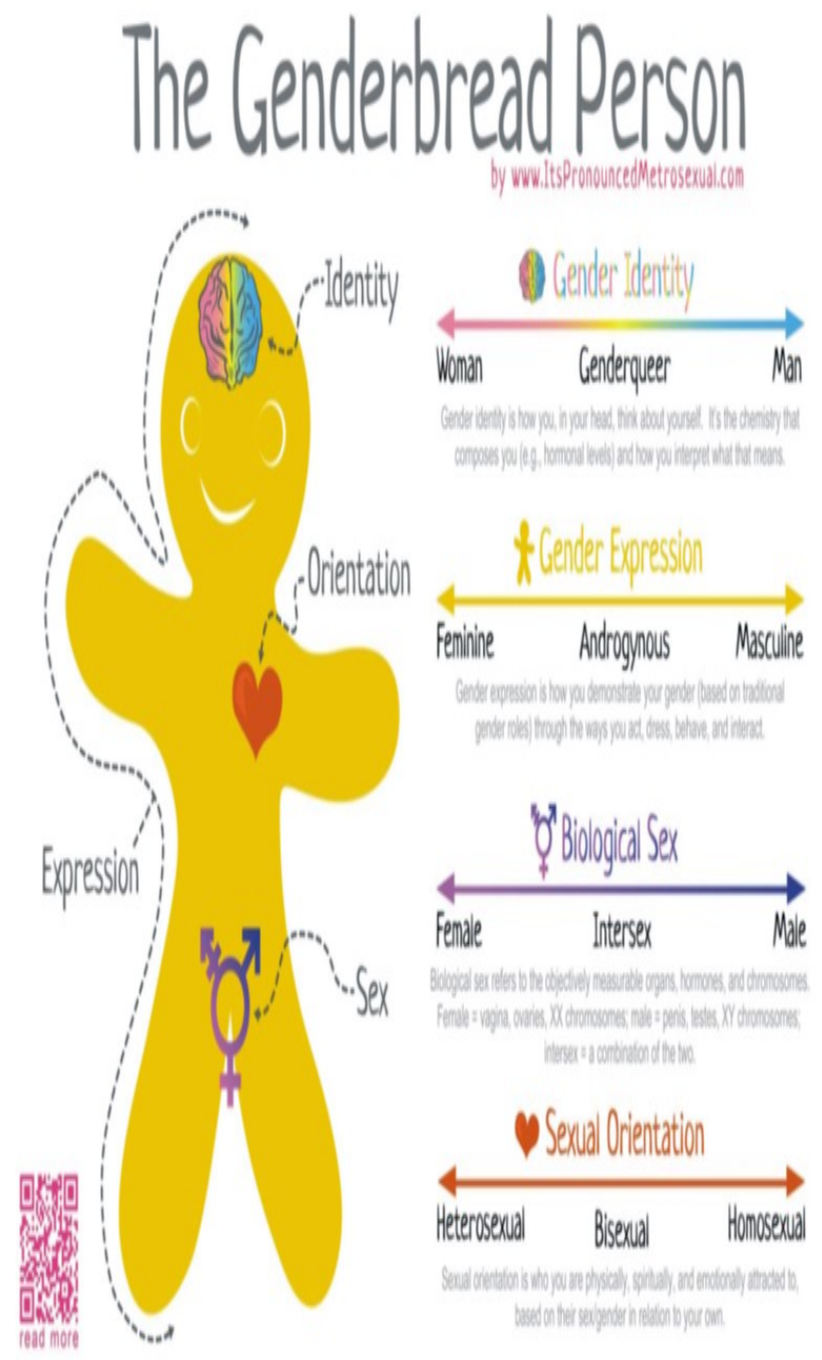

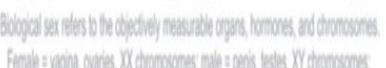

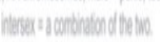

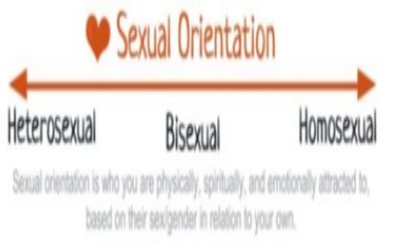

Gambar 1. The Genderbread Person (Killerman, 2011 dalam Laazulva, 2013)

Gambar diatas menjelaskan bagaimana "the Genderbread" person dikonstruksikan melalui:

1. Gender Identity adalah di mana seorang individu merasa nyaman menjadi seorang laki-laki atau perempuan bisa sesuai dengan jenis kelaminnya atau tidak sesuai.

2. Gender Expression adalah cara pandang individu merepresentasikan dirinya di lingkungan dengan budaya tertentu. Ekspresi gender berkaitan dengan maskulin dan feminin, tetapi ada juga gender nonconforming (androginy: tidak 
Jurnal Pemikiran Sosiologi Volume 6 No.2 2019

Heteronormativitas, Wacana LGBT dan Perjuangan Komunitas Waria Melawan Stigma

Inestya Kartikaningdryani

mempermasalahkan mau berpenampilan seperti apa).

3. Biological Sex adalah jenis kelamin sesuai dengan organ-organ reproduksi ketika seseorang dilahiran. Secara umum, hanya ada laki-laki dan perempuan, tetapi ada kemungkinan seorang individu lahir dengan dua jenis kelamin (intersex).

4. Orientasi Sexual adalah kecenderungan untuk menyukai lawan jenis atu sesama jenis berdasarkan ketertarikan emosional, fisik dan seksual.

Di antara kelompok LGBT, waria yang masuk dalam dalam kelompok $\mathrm{T}$ (Transgender) paling rentan mengalami diskriminasi karena secara penampilan fisik mereka paling mudah dikenali. Tom Boellstorff (2004:29) mengatakan "waria diakui, tetapi pada umumnya dikenal sebagai orang bawah atau menyimpang". Tidak banyak waria yang berasal dari keluarga yang berada. Bagi mereka yang hidup di kalangan menengah ke bawah, jalanan merupakan lapangan pekerjaan yang bisa menerima mereka. Sulit bagi waria untuk dapat masuk ke sektor formal karena perusahaan atau instansi pemerintah tempat melamar sering mengaitkan waria dengan HIV/AIDS. Akibatnya, tidak jarang waria yang memilih untuk menjadi pengamen atau pekerja seks guna memenuhi kebutuhan hidup sehari-hari.

Orang-orang yang tereksklusi dari masyarakat ini kemudian mencari jalan untuk bertahan hidup, salah satunya adalah dengan membentuk komunitas. Di dalam kelompok inilah mereka bisa mengekspresikan diri mereka sendiri, tanpa harus ada yang ditutup-tutupi. Di Yogyakarta sendiri sudah ada banyak komunitas waria, tiga di antaranya Lembaga Swadaya Masyarakat (LSM) Kebaya, Ikatan Waria Yogyakarta (IWAYO) dan Pondok Pesantren Waria Al Fattah. Hal ini menjadi menarik untuk dikaji jika menilik kembali stigma yang disematkan kepada waria. Mereka yang diidentikkan dengan dunia malam dan HIV/AIDS, justru mampu mengelola komunitas-komunitas hingga terbentuk jaringan-jaringan besar dan dikenal masyarakat luas. Akhirnya pertanyaan penelitian yang dapat ditarik adalah: bagaimana waria mengorganisasikan dirinya menjadi komunitas? Bagaimana strategi pengelolaan komunitas waria?

\section{B. Metode dan Kerangka Analisis}

Penelitian ini menggunakan pendekatan kualitatif dengan metode etnografi komunitas dan etnografi feminis. Brunt (2001: 84) mengatakan, "the first thing to be mentioned about community studies is perhaps that they remind us time and again of the subjectiveness and onesidedness of social perception". Etnografi komunitas memungkinkan peneliti untuk mengkaji bagaimana waria berperilaku dan saling berinteraksi hingga akhirnya mengasosiasikan diri mereka ke dalam sebuah komunitas berdasarkan pengalaman mereka. Metode etnografi feminis digunakan karena mengingat posisi waria yang termarjinalkan. Melalui metode ini memungkinkan peneliti untuk memiliki sudut pandang dari orang-orang yang teropresi atau istilahnya "giving voice" (Skeggs, 2001).

Yogyakarta dipilih menjadi lokasi penelitian karena terdapat beragam elemen yang membentuk 
Jurnal Pemikiran Sosiologi Volume 6 No.2 2019

Heteronormativitas, Wacana LGBT dan Perjuangan Komunitas Waria Melawan Stigma

Inestya Kartikaningdryani

kota tersebut, salah satunya adalah waria. Berdasarkan database LSM Kebaya pada 2017, tercatat ada 350 waria yang berada di Yogyakarta, sekitar 86 waria berasal dari luar daerah. Situasi kota yang cukup kondusif saat ini, menjadi daya tarik waria untuk memilih tinggal di Yogyakarta. Waria di Yogyakarta bisa dikelompokkan ke dalam beberapa komunitas perwilayah. Setidaknya ada 10 titik, diantaranya wilayah Badran, Kricak Sidomulyo, Bantul dan Kulonprogo. Penelitian ini hanya melibatkan tiga komunitas waria induk, yakni LSM Kebaya, Pondok Pesantren Waria Al-Fattah dan IWAYO.

Penelitian ini menggunakan tiga teori, yakni performativitas, community development theory, dan gerakan sosial dalam perspektif LGBT.

\section{(1) Performativitas}

Konsep performativitas diperkenalkan oleh seorang filsuf post-strukturalis Amerika, Judith Butler. Menurut Butler, gender atau seksualitas seperti drag, kontes kecantikan yang dilakukan oleh waria untuk menguji dan membuktikan bahwa mereka telah menghasilkan feminitas yang sebenarnya (Alimi, 2013). Dalam konsep performativitas, tidak ada gender asli, yang ada proses imitasi yang terus berulang sehingga membentuk gender yang dianggap "asli".

Gender dan seksualitas yang sudah dimapankan ini menjadi bagian dari proyek normalisasi heteroseksualitas. Butler menegaskan heteroseksualitas bukanlah konstruk alamiah, melainkan dinaturalkan dengan peniruan yang diulang-ulang, yang beroperasi melalui devaluasi, stigmatisasi dan abonormalisasi seksual lainnya
(Alimi, 2004). Akibatnya, orang-orang yang gagal menyesuaikan kemapanan gender dan seks dianggap menyimpang.

Dalam konteks waria, teori performativitas bisa digunakan untuk menelusuri tindakantindakan yang dilakukan waria dalam mengaktualisasi identitas gender ketiga. Bisa jadi waria yang satu dengan yang lainnya memiliki keyakinan yang berbeda mengenai konsep perempuan ideal. Hal ini juga tidak lepas dari hegemoni heteroseksualitas yang patriarkis, di mana seksualitas hanya untuk tujuan prokreasi melalui proses naturalisasi norma-norma heteroseksual yang diulang-ulang (Alimi, 2013). Maka dari itu, teori performativ juga bisa menganalisis bagaimana tindakan performativ mempengaruhi tindakan waria mengenai menjadi perempuan.

\section{(2) Community Development Theory}

Pengorganisasian komunitas berdasarkan gender muncul akibat adanya pembagian ruang publik yang membuat ruang gerak perempuan terbatasi, sehingga memposisikan diri mereka sebagai subordinat. Stall dan Stoecker (2012) menawarkan dan membandingkan dua model pengorganisasian komunitas berdasarkan gender, yakni model Alinski dan model yang berpusat pada wanita (women-centered model). Kedua model ini sama-sama berangkat dari tingkat lingkungan daerah tempat tinggal (neighborhood) yang diperluas dengan adanya gerakan-gerakan sosial (Stall dan Stoecker, 2012). Dalam komunitas, perempuan digerakkan sebagai motor perubahan sosial. 
Jurnal Pemikiran Sosiologi Volume 6 No.2 2019

Heteronormativitas, Wacana LGBT dan Perjuangan Komunitas Waria Melawan Stigma

Inestya Kartikaningdryani

Perbedaan mendasar pada model Alinski adalah perempuan diajari untuk dapat beradaptasi dengan keadaan di ranah publik oleh professional organizer, yang merupakan outsider dalam komunitas dan biasanya adalah para profesional yang dibayar. Professional organizer ini juga bisa menjadi pemimpin dalam komunitas, tetapi tetap dibutuhkan pemimpin yang asli dari komunitas tersebut. Sedangkan women-centered model, komunitas menjadi wadah bagi sesama perempuan untuk saling berdaya. Model ini diawali dengan membangun kesadaran kolektif dan solidaritas sesama perempuan melalui kegiatan sukarela, seperti pelayanan sosial, pendidikan, buruh, perumahan, kesehatan dan hak anak (Berg, 1978; Tax, 1980 dalam Stall dan Stoecker, 2012).

Kedua model ini bukannya tidak mendapat kritikan. Model Alinski dinilai tidak sensitif dengan isu perempuan dan tidak menyediakan pelatihan yang cukup bagi perempuan (Reitzes \& Reitzes, 1987 dalam Stall dan Stoecker, 2012). Sedangkan women-centered model, aksi kolektif yang dilakukan oleh perempuan cenderung dilihat sebagai aksi amal daripada kegiatan sosial (Brandwein, 1987; Finks, 1984 dalam Stall dan Stoecker, 2012) dan terlalu menekankan pada pelayanan individual daripada reformasi sosial dan perkembangan komunitas (Specht \& Courtney, 1994 dalam Stall dan Stoecker, 2012).

Dalam perkembangan komunitas, penelitian ini menambahkan pandangan Judith Garber yang sebenarnya mengkritisi teori pembentukan komunitas yang terlalu kaku. Komunitas bagi Garber tidak serta merta terbentuk begitu saja. Misalnya, hanya karena di daerah $\mathrm{X}$ banyak waria lalu muncul komunitas waria di daerah tersebut. Justru, dalam pandangan Garber, karena banyak waria lain yang kemudian ikut mendiami daerah tersebut, dalam istilah Garber (2012) communities of choice or identity groups against communitites of place. Hal inilah yang menjadi kritik Garber atas teori komunitas kuno yang berorientasi pada tempat.

Dalam konteks kota beserta kehidupan berpolitiknya, komunitas menjadi kendaraan untuk mengakomodir suatu perubahan (Garber, 2012). Garber melihat perempuan yang kehidupannya termarginalkan di kota-kota. Dengan bergabungnya mereka dalam komunitas, kesadaran akan berpolitik meningkat, mereka sadar atas subordinasi yang terjadi pada mereka dan mengapa bisa demikian. Mengutip pernyataan Garber (2012) “...political activity by coalitions of women aimed spesifically at defining inclusive, good communities might result in localities that are less marginalizing, hierarchical and dangerous." Dengan begitu, baik komunitas formal maupun informal menjadi sumber potensial pemberdayaan perempuan dan perubahan politik.

Dengan menggunakan kedua pandangan di atas, penelitian ini akan mengurai benang kusut permasalahan dalam komunitas waria di Yogyakarta. Pandangan Stall dan Stoecker menawarkan elaborasi mengenai bagaimana waria mengasosiasikan dirinya ke dalam komunitas dan pola pengorganisasi komunitas waria. Sedangkan pandangan Garber menawarkan elaborasi mengenai bagaimana komunitas waria berpartisipasi dalam kehidupan berpolitik di area Yogyakarta yang bertujuan untuk afirmasi identitasnya sekaligus melawan diskriminasi terhadap mereka. Hal ini karena mengingat pada awalnya komunitas waria 
Jurnal Pemikiran Sosiologi Volume 6 No.2 2019

Heteronormativitas, Wacana LGBT dan Perjuangan Komunitas Waria Melawan Stigma

Inestya Kartikaningdryani

muncul sebagai ruang yang aman bagi waria untuk dapat terus bertahan hidup. Namun, seiring dengan berjalannya waktu, tekanan yang dihadapi oleh waria semakin kompleks, seperti kematian waria karena HIV/AIDS, dan mendorong mereka untuk membuat sebuah gerakan sosial.

\section{(3) Gerakan Sosial dalam Perspektif LGBT}

Berbicara mengenai gerakan sosial tidak bisa dilepaskan dari identitas kolektif. Polletta dan Jasper (2001) melihat bahwa identitas berperan dalam empat fase gerakan sosial, yakni penciptaan klaim kolektif, motivasi orang-orang untuk bertindak, memilih strategi gerakan, dan efek dari gerakan sosial. Olson (1965 dalam Polletta dan Jasper, 2001) mengatakan "shared interests are simply not enough to motivate individual effort in the absence of selective rewards that go only to participant". Dalam gerakan kolektif ada preexisting solidarities, seseorang sebelumnya telah memiliki ikatan dengan orang lain yang membuat suatu hubungan timbal balik. Sehingga ketika gerakan mereka sedang mengalami masa darurat, ada pertolongan dari jaringan ini. Gerakan kolektif juga memframing identitas mereka, identitas ini yang membedakan "kami” dengan "kalian”.

Dalam membahas mengenai strategi gerakan, penulis menggunakan analisis dalam kacamata Bernstein. Bernstein menganalisis penggunaan identitas sebagai strategi dalam gerakan homophile ke dalam dua jenis, identitas untuk kritik (identity for critique) dan identitas untuk mengedukasi (identity for education). Identitas untuk kritik menentang nilai-nilai, kategori-kategori dan praktek-praktek dalam kultur dominan mengenai peran gender yang teralamiahkan dan seksualitas untuk melanjutkan keturunan; sedangkan identitas untuk mengedukasi menantang persepsi umum mengenai minoritas atau digunakan secara strategis untuk mendapatkan legitimasi dengan tidak mempermainkannya dalam motif yang kontroversial, mereka menunjukkan identitasnya sebagai homoseksual yang berkebalikan dengan stereotype masyarakat (Bernstein, 1997). Kedua strategi ini digunakan tergantung pada kondisi lokal: akses politik dan bentuk-bentuk perlawanan yang dihadapi oleh gerakan homophile.

Pada akhirnya, identitas juga bisa menjadi tujuan dari aktivisme gerakan sosial, mendapatkan pengakuan atas identitas yang terstigma hingga sekarang (Calhoun, 1994 dalam Bernstein, 1997) maupun mendekonstruksi ketegori-kategori identitas seperti "laki-laki”, "perempuan”, "gay" dan "straight" (Gamson, 1995 dalam Bernstein, 1997). Selain itu, Polleta dan Jasper (2001) menambahkan bahwa aksi kolektif ini juga mendorong munculnya aksi tandingan. Aksi tandingan ini menurut Bernstein (1997) ada dua jenis, organized opposition dan routine opposition.

Sebagai kelompok yang paling visible, waria memiliki kerentanan terhadap kekerasan dan diskriminasi yang paling tinggi. Dengan menggunakan kacamata gerakan sosial ini, penelitian ini berusaha mengkaji strategi yang dilakukan komunitas waria dalam menghadapi represi yang mereka alami. Bagaimana mereka menumbuhkan rasa solidaritas yang mungkin tidak terbatas di kalangan waria saja, namun seluruh elemen masyarakat; kapan mereka akan 
Jurnal Pemikiran Sosiologi Volume 6 No.2 2019

Heteronormativitas, Wacana LGBT dan Perjuangan Komunitas Waria Melawan Stigma

Inestya Kartikaningdryani

menggunakan identitas untuk mengkritik dan identitas untuk mengedukasi.

\section{Kondisi Umum Waria di Yogyakarta dan Pembagian Citra dalam Diri Waria}

Pada dasarnya waria memiliki mobilitas yang tinggi. Mereka hidup dengan berpindah-pindah tempat. Yogyakarta menjadi destinasi favorit waria untuk singgah dengan beberapa alasan. Pertama, kondisi di Yogyakarta terhitung cukup kondusif bagi waria untuk tinggal maupun bekerja. Kedua, layanan kesehatan di Yogyakarta lebih mudah diakses daripada daerah lainnya, sehingga banyak waria yang datang ke Yogyakarta untuk berobat.

Kehadiran waria di Yogyakarta sebenarnya menghadapi posisi dilematis. Di satu sisi, waria dapat diterima di masyarakat. Bahkan kampung Kricak, Sidomulyo, bersedia menguburkan jenazah waria (ada 17 waria yang dimakamkan di kompleks pemakaman kampung Kricak, Sidomulyo). Namun di sisi lain, kewariaan mereka dianggap abnormal karena tidak bisa menyesuaikan dengan normanorma kemasyarakatan. Sehingga, mereka kerap menerima perlakuan diskriminatif bahkan cenderung anarkis. Penindasan yang dialami waria merupakan penindasan berlapis, pertama mereka ter-exclude dari masyarakat dan kedua mereka berasal dari kelompok miskin sehingga sulit bagi mereka untuk dapat mengakses layanan publik.

Secara anatomis, waria adalah laki-laki, tetapi memiliki "panggilan jiwa" sebagai perempuan. Panggilan jiwa ini tumbuh saat masa anak-anak dan akan mencapai puncaknya pada

masa pubertas. Di masa pubertas, waria mulai mempertanyakan identitas mereka karena dalam lingkungan heteronormativitas seharusnya laki-laki menyukai perempuan. Namun, pada waria yang terjadi sebaliknya. Pada proses pencairan identitas inilah waria mulai mendapat penolakan dari lingkungan terdekat mereka. Beberapa waria memilih kabur dari rumah karena kewariaan mereka dianggap sebagai aib keluarga, meskipun hal ini tidak bisa digeneralisir.

Penerimaan oleh keluarga merupakan suatu privilege. Penerimaan ini mempengaruhi kehidupan waria selanjutnya, misalnya menyelesaikan studi hingga perguruan tinggi dan memiliki Kartu Tanda Penduduk (KTP). KTP menjadi hal yang paling esensial bagi seorang warga negara. Di sinilah masalah mendasar bagi waria, karena sebagian besar waria pergi dari rumah di usia remaja dan ketika harus mengurus pembuatan KTP mereka diharuskan membawa Kartu Keluarga (KK) sebagai salah satu syaratnya. Masalahnya, tidak semua waria yang pergi dari rumah masih memiliki hubungan yang baik dengan keluarganya, sehingga proses pembuatan KTP mereka terhambat. Tidak adanya KTP mempengaruhi keterbatasan akses mereka ke layanan publik.

Selain KTP, masalah yang dihadapi waria adalah finansial. Salah satu cara bertahan hidup waria yang pergi dari rumahnya adalah dengan turun ke jalanan. Pelacuran di jalanan menjadi satu fase yang hampir dialami semua waria. Di jalanan, waria rentan menerima pelecehan, terjaring razia hingga pembunuhan.

Dalam kacamata Judith Butler mengenai kontes drag queen, waria sebenarnya tidak sedang 
Jurnal Pemikiran Sosiologi Volume 6 No.2 2019

Heteronormativitas, Wacana LGBT dan Perjuangan Komunitas Waria Melawan Stigma

Inestya Kartikaningdryani

menirukan yang asli, justru mereka sedang memparodikan, menunjukkan bahwa yang dianggap "asli" itu tidak ada. Waria bisa jadi pembuktian bahwa gender itu cair dan tidak stabil, identitas mereka dibentuk oleh tindakan performatif seharisehari melalui praktik-praktik tubuh. Sama halnya dengan waria yang ada di Yogyakarta, tidak semua waria akan berdandan. Cara waria mengekspresikan kewariaan/panggilan jiwa perempuan ini tergantung pada kenyamanan individu masingmasing, ada waria feminin dan waria tomboy. Bagi waria feminine, anggapan umum mengenai perempuan berbulu adalah jelek dan tidak anggun mendorong mereka bahkan untuk melampaui perempuan "sesungguhnya", mereka terobsesi untuk memiliki kulit yang halus tanpa bulu. Scott Siraj al-Haqq Kugle (2014) dalam bukunya "Living Out Islam, Voices of Gay, Lesbian and Transgender Muslim" bahkan mengatakan "striking people as "natural"-looking and acting as much like a feminine woman as possible- is her goal". Pernyataan Kugle ini merujuk pada salah satu aktivis trangender male to female di Afrika Selatan yang menjadi informan dalam studinya. Dalam konteks waria di Yogyakarta, ada juga yang mengenakan simbol-simbol agama seperti jilbab atau kerudung untuk menunjukkan feminitasnya. Artinya, ada dua identitas yang sebenarnya ingin mereka tunjukkan, bahwasanya mereka waria yang ingin merubah pandangan umum mengenai waria sebagai pendosa dan sebagainya.

Agar dapat mengekspresikan identitasnya, waria cenderung menciptakan ruang bersama sesamanya. Perlu dicatat bahwa waria memiliki identitas yang beragam dan di ruang ini terjadi cross-cutting identitas waria sebagai transgender, yang juga menjadi identitas sosial mereka. Melalui representasi identitas sosial, waria ingin mengurangi stigma negatif yang sering diasosiasikan dengan mereka. Mereka menyadari bahwa untuk mewujudkan hal itu diperlukan aksi kolektif, maka ruang ini tidak hanya menjadi ajang kumpul-kumpul, tetapi dikembangkan menjadi komunitas waria yang berdaya.

Di bidang pekerjaan ada komunitas waria pengamen, pelacur dan pekerja salon. Widayanti (2009) mengatakan bahwa waria pekerja salon merupakan waria elit, karena tidak semua waria memiliki ketrampilan untuk dapat bekerja di salon atau bahkan mengelola salon. Sedangkan waria pengamen berada di "kasta" paling bawah karena mereka menjual rasa kasihani diri. Komunitas waria di Yogyakarta yang paling awal muncul adalah komunitas dalam skala tempat tinggal. Biasanya waria akan tinggal di daerah yang sudah ada waria lainnya, lama kelamaan semakin banyak waria yang datang dan mendiami daerah tersebut. Di Yogyakarta ada 10 titik komunitas waria dalam skala tempat tinggal, di antaranya: kampung Badran, Kricak, Kotagede, Waria Kulon Progo (Warkop), dan Bantul.

Banyaknya komunitas waria ini dipayungi oleh tiga komunitas waria induk yang bergerak dalam isu yang berbeda, yakni Pondok Pesantren Waria Al-Fattah, LSM Kebaya dan IWAYO. Pondok Pesantren Waria Al-Fattah bergerak di isu religiusitas, LSM Kebaya bergerak di isu kesehatan, utamanya penanggulangan HIV/AIDS, dan IWAYO bergerak di isu advokasi. Ketiga komunitas tersebut sama-sama berjuang untuk memperjuangkan hak- 
Jurnal Pemikiran Sosiologi Volume 6 No.2 2019

Heteronormativitas, Wacana LGBT dan Perjuangan Komunitas Waria Melawan Stigma

Inestya Kartikaningdryani

hak waria, utamanya dalam mengakses layanan publik. Dalam komunitas, waria membayangkan dirinya sebagai satu entitas atas kesamaan nasib dan identitas. Sehingga dalam kepengurusan ketiga komunitas tersebut tetap melibatkan warianya itu sendiri. Mereka bergerak menjalankan kepengurusan dengan berlandaskan kerjasama, istilahnya dari waria, untuk waria dan oleh waria.

Ketiga komunitas ini menjadi titik komunikasi antara waria dan menjadi "kendaraan" waria untuk meng-counterframing anggapan buruk mengenai waria melalui kegiatan kemasyarakatan. Dengan adanya kontibusi yang positif, keberadaan waria perlahan-lahan akan diterima. Berdasarkan pengamatan di lapangan, hanya Pondok Pesantren Waria Al-Fattah yang konsisten memiliki kegiatan rutin setiap minggunya. Sehingga, bisa dibilang dalam studi ini ada lebih banyak pembahasan mengenai Pondok Pesantren Waria Al-Fattah. Meskipun begitu, teman-teman waria baik yang ada di Pondok Pesantren Waria Al-Fattah, LSM Kebaya maupun IWAYO merupakan orang-orang yang sama. Sebab, dalam komunitas waria di Yogyakarta terdapat beberapa posisi strategis yang hanya bisa diduduki oleh waria tertentu. Mereka adalah waria senior atau dalam istilah Widayanti (2009) broker yang menjembatani interaksi antara waria dalam komunitas dengan pihak eksternal, mereka juga menjadi representasi identitas waria (role model). Keberlangsungan komunitas induk waria tidak lepas dari pengaruh waria senior karena mereka memiliki citra sebagai sosok yang mengayomi waria-waria lain. Selain dari umur yang lebih tua, waria senior ini disegani juga karena modal yang mereka miliki.
Maka waria senior biasanya mengisi posisi kepengurusan tertinggi di dalam komunitas.

Waria yang menjadi informan dalam penelitian ini memiliki peran sebagai pengajar, perawat dan pelayan; perempuan salih; dan aktivis. Peran ini tidak hanya mereka lakukan kepada komunitas saja, tetapi juga mereka bawa ke luar komunitas waria sebagai representasi identitas sosial sebagai waria. Waria sebagai pengajar, perawat dan pelayan mendedikasikan dirinya untuk mensejahterakan sesamanya. Glenn, dkk (1994 dalam Stall dan Stoecker, 2012) mengatakan bahwa dalam kacamata women-centered model melihat aktivitas komunitas dimulai dari peran-peran tradisional perempuan dalam mengasuh, tidak secara biologis, tetapi berangkat dari "a socially constructed set of activities and relationship involved in nurturing and caring for people". Kegiatan kerelawaan teman-teman waria sebenarnya bermula dari hal sederhana dan dari lingkup yang terkecil: orang-orang disekitar mereka, mereka memiliki kesadaran "kalau bukan saya, siapa lagi" yang akan membantu mereka. Dari hal sederhana seperti ini kemudian mereka kembangkan dengan serius dan menjadi suatu komunitas yang menampung orang-orang yang lemah secara ekonomi dan sumber daya. Dedikasi dan komitmen dalam upaya untuk mensejahterakan sesamanya menghantarkan beberapa diantara mereka menjadi waria yang berpengaruh. Sehingga, tidak jarang mereka juga dipanggil dengan sapaan keibuan: "mami", "ibu", "bunda".

Waria ingin menunjukkan eksistensinya sebagai perempuan dari sudut pandang agama dengan mengenakan jilbab. Sehingga, mereka 
Jurnal Pemikiran Sosiologi Volume 6 No.2 2019

Heteronormativitas, Wacana LGBT dan Perjuangan Komunitas Waria Melawan Stigma

Inestya Kartikaningdryani

mencitrakan dirinya dengan identitas sebagai perempuan salih. Pertumbuhan wacana agama dalam konteks waria berjilbab seperti dua sisi mata koin. Di satu sisi, dibebaskannya masyarakat dalam memenuhi kebutuhan religius dan spiritual dalam pandangan penulis dapat diibaratkan seperti pintu yang terbuka, banyak orang yang berlomba-lomba untuk masuk terlebih dahulu. Sama halnya dengan waria yang ikut menunggangi wacana agama yang sedang naik daun ini untuk menunjukkan eksistensinya melalui simbol agama, jilbab. Di sisi lain, seperti yang dikatakan Scott Siraj al-Haqq Kugle sebelumnya, tampak sealami mungkin seperti perempuan merupakan suatu tujuan bagi waria. Sama halnya dengan suntik botox ataupun hormon, jilbab juga diadposi atas alasan yang sama: the pursuit of an idealized feminine beauty and the quest for an identity and acceptance (Candraningrum, 2013).

Dalam mengamati pergerakan komunitas perempuan dalam wilayah urban, Wekerle (1998 dalam Garber, 2012) mengatakan "women joined the co-ops not only for affordable shelter but also to attain certain political ideal, mutual support and, according to resident, "to share responsibilities, rights and democracy". Untuk melawan ketidakadilan yang terjadi pada perempuan tidak berhenti pada menciptakan ruang yang nyaman untuk mereka saling berbagi rasa sependeritaan, lebih dari itu dibutuhkan kesadaran untuk bersama-sama mengatasi permasalahan tersebut melalui aksi kolektif. Dengan begitu, komunitas memerlukan sosok penggerak yang mendorong tumbuhnya kesadaran anggota lainnya demi mewujudkan citacita mereka. Di sinilah muncul waria sebagai aktivis.
Kegiatan mereka tidak lepas dari perjuangan advokasi hak-hak waria, khususnya di Yogyakarta.

\section{Wacana LGBT Melawan Stigma: Waria, Politik Identitas dan Masalah Sosial}

Aksi vigilantisme terhadap kelompok minoritas dan tersubordinat di Yogyakarta meningkat. Dalam laporannya "Krisis Keistimewaan, Kekerasan terhadap Minoritas di Yogyakarta”, Ahnaf dan Salim (2017) mencatat setidaknya total ada 71 kasus kekerasan dalam kurun waktu 2000-2016. Adalah FJI dan FUI yang menjadi dalang dalam tindakan dalam kasus-kasus vigilantisme yang membawa sentiment agama. Menariknya, kedua kelompok ini menghindari tuduhan terkait jaringan terorisme, seperti Jamaah Islamiyah dan kelompok Osama bin Laden. Sehingga, kedua kelompok ini menyasar kegiatan yang berbau "promosi" LGBT, komunisme dan kegiatan yang dianggap anti-Islam.

Salah satu kasus vigilantisme yang cukup masif diberitakan media adalah penutupan paksa Pondok Pesantren Waria Al-Fattah oleh FJI. Ahnaf dan Salim (2017) berpendapat bahwa meningkatnya kasus-kasus vigilantisme ini tidak lepas dari dinamika sosio-struktural yang bisa jadi dipengaruhi oleh beberapa hal. Pertama, absennya negara dalam menanggapi kasus intoleransi di Yogyakarta. Kedua, pembangunan hotel, mal dan apartemen yang tidak terkendali, serta masalah pertanahan yang mendapat penolakan dari masyarakat.

Di sisi lain, pemerintah daerah Yogyakarta telah mengesahkan Peraturan Daerah (Perda) Nomor 1/2014 tentang penanganan gelandangan 
Jurnal Pemikiran Sosiologi Volume 6 No.2 2019

Heteronormativitas, Wacana LGBT dan Perjuangan Komunitas Waria Melawan Stigma

Inestya Kartikaningdryani

dan pengemis (gepeng). Perda ini berangkat dari kewajiban pemerintah untuk menjamin dan meningkatkan kesejahteraan setiap warga negara dan kelompok-kelompok yang rentan, salah satunya adalah gepeng. Dalam perda ini, gepeng dianggap sebagai kelompok masyarakat miskin dan rentan. Oleh karena itu, perda gepeng hadir untuk menjadi solusi yang efektif.

Namun, praktik di lapangan menyajikan fakta yang berbeda. Perda ini dinilai bermasalah karena beberapa alasan di antaranya: (1) Kriteria gepeng yang dinilai subjektif sehingga siapapun dapat menjadi target razia. (2) Prosedur penanganan dan upaya rehabilitasi yang tidak manusiawi. Selama 21 September hingga 24 November 2015, Kaukus Perda Gepeng menemukan 23 kasus kekerasan dan pelanggaran Hak Asasi Manusia (HAM) dalam penerapan perda ini. (3) Upaya paskarehabilitasi yang mematikan aktivitas ekonomi target razia.

Dalam konteks waria, terutama yang berprofesi sebagai pekerja seks, bisa terkena perda berlapis, yakni Perda Gepeng dan Perda DIY Nomor 18/1954 tentang pelacuran di tempat umum. Keberadaan perda ini membuat waria lebih rentan terhadap diskriminasi dan penindasan. Sehingga, komunitas waria perlu menjalin kerja sama dengan komunitas/organisasi lainnya, seperti Kaukus Perda Gepeng dan LBH Yogyakarta. Namun perlu diingat, dalam advokasi perda gepeng ini, LSM Kebaya sebagai komunitas waria belum berani secara terbuka ikut dalam gerakan ini. Hal ini dikarenakan LSM Kebaya menjalin kerja sama dengan Dinas Sosial (Dinsos) yang notabene merupakan institusi pemerintah.
Kasus vigilantisme dan Perda Gepeng membuat posisi kelompok waria semakin termarginalkan. Marginalisasi yang mereka alami menimbulkan kebutuhan untuk mempertahankan identitas mereka dalam masyarakat juga di hadapan negara (Saputra, 2016). Marginalisasi membangkitkan kesadaran mereka untuk melawan ketidakadilan melalui strategi klaim atas identitas. Bernstein (1997) mendefinisikan organisasi gerakan inklusif sebagai kelompok-kelompok yang dalam praktiknya berusaha untuk mendidik (educate) dan memobilisasi massa atau memaksimalkan keterlibatan dalam kampanyekampanye politik.

Dalam menghadapi tekanan yang lebih terorganisir dan secara terang-terangan, komunitas waria menggunakan strategi identity for critique, meskipun tidak menutup kemungkinan mereka menggunakan kedua model strategi sekaligus. Dengan adanya jaringan, mereka lebih pede dalam menunjukkan identitasnya di hadapan publik. Secara tidak langsung, Kymlicka mengungkapan bahwa kemunculan politik identitas dikarenakan resistensi terhadap politik homogenisasi budaya dalam sebuah negara bangsa (Kymlicka, 2003: 1-12 dalam Saputra, 2016).

Secara luas, politik identitas dapat diartikan sebagai aksi politik yang berorientasi pada kebutuhan, nilai-nilai dan kepentingan dari sebuah kelompok yang memiliki kesamaan identitas (Saputra, 2016). Ada sesuatu yang dishare dalam kelompok tersebut. Dengan identitas tersebut, ada loyalitas dan solidaritas untuk mempertahankan dan mengekspresikan identitas komunitasnya (Widayanti, 2009). Pembahasan mengenai strategi 
Jurnal Pemikiran Sosiologi Volume 6 No.2 2019

Heteronormativitas, Wacana LGBT dan Perjuangan Komunitas Waria Melawan Stigma

Inestya Kartikaningdryani

politik identitas dalam konteks komunitas waria dibagi menjadi dua bagian, yakni eksternal dan internal.

\section{1. Strategi Eksternal: Politik dan Gerakan Kelompok Waria}

Dalam melihat strategi politik dan gerakan kelompok Waria, Jamson (2016) berpendapat:

"Strategi politik identitas adalah berkaitan dengan mekanisme politik pengorganisasian identitas (baik identitas politik maupun identitas sosial) sebagai sumber daya dan sarana untuk klaim rekognisi. Klaim politik rekognisi sering mengambil bentuk dengan cara menarik perhatian publik, ataupun upaya-upaya performative atas identitas mereka, menegaskan spesifitas dari kelompok mereka, dan kemudian dari menegaskan nilai spesifitas itu. Sehingga mereka cenderung untuk mempromosikan differensiasi kelompok."

Politik identitas dalam konteks komunitas waria adalah untuk merekonstruksi cara pandang masyarakat umum mengenai citra mereka yang selama ini dianggap menjadi akar penindasan dan perampasan hak-hak mereka. Tindakan-tindakan simbolis menjadi modal bagi komunitas dalam upaya penegasan identitasnya. Tindakan simbolis merupakan sebuah mekanisme penegasan identitas, setidaknya untuk mempertahankan eksistensi individu atau kelompok (Kinasih, 2005: 4 dalam Saputra, 2016). Melalui tindakan-tindakan ini, waria baik dalam komunitas maupun individual berupaya untuk menegaskan identitas mereka.
Ketika keberadaan mereka dapat diterima, mereka pun dapat melakukan upaya yang lebih besar lagi yang dilakukan bersama komunitas. Strateginya adalah melakukan kegiatan yang melibatkan waria dalam jumlah yang banyak dan mengambil lokasi di pemukiman warga yang jarang ada warianya seperti yang dilakukan LSM Kebaya maupun Pondok Pesantren Waria Al-Fattah. Keduanya tidak berlokasi di kampung waria untuk menghindari eksklusivitas. Sehinnga, lokasi ini menjadi kesempatan bagi mereka untuk show up kepada masyarakat sekitar. Kegiatan yang mereka lakukan merupakan strategi counterframing, di mana mereka menyerang secara halus citra negatif yang selama ini dilekatkan kepada waria. Misal, ketika pandangan umum mengidentikkan waria dengan pendosa dan kehidupan malam, hal ini disanggah oleh kegiatan pengajian waria yang ada di Pondok Pesantren Waria Al-Fattah. Begitu pula dengan waria yang diidentikkan dengan HIV/AIDS, LSM Kebaya (pada awal berdirinya) berupaya memberi edukasi mengenai bahaya dan penularan HIV/AIDS dalam rangka menekan angka ODHA di kalangan waria.

Dalam konteks gerakan, Jamson (2016) menemukan bahwa setelah 2016, pola gerakan dalam melakukan klaim identitas oleh komunitas waria mengalami transfomasi. Sebagai sumber kekuatan, pola gerakannya kini berkonsolidasi berbasis kelas ekonomi dengan gerakan masyarakat lain. Hal ini diamini oleh Bernstein (1997) yang mengatakan "when an emergent movement lacks both political acces and an organizational infrastructure or collective identity, then an emphasize on difference will be needed to build 
Jurnal Pemikiran Sosiologi Volume 6 No.2 2019

Heteronormativitas, Wacana LGBT dan Perjuangan Komunitas Waria Melawan Stigma

Inestya Kartikaningdryani

solidarity and mobilize a constituency". Gerakan semacam ini akan lebih cenderung merayakan perbedaan, karena meskipun berbeda identitas personal, tetapi mereka ditekan oleh kelompok yang sama melalui tindakan-tindakan yang sama. Dengan konsolidasi dengan jaringan lain, mereka dapat memobilisasi masa dan aksi berhadapan langsung dengan kelompok tandingan.

Terlihat dari jaringan yang dibentuk oleh IWAYO dalam melakukan advokasi, jaringan berfungsi sebagai back up komunitas. Dalam gerakan menolak Perda Gepeng, misalnya, IWAYO bergabung dengan jaringan yang lebih besar, Kaukus Perda Gepeng dan Komnas HAM, karena sebenarnya yang merasa dirugikan dengan adanya Perda Gepeng tidak hanya dari kalangan waria, tetapi juga remaja jalanan, perempuan pekerja seks, pengemis, dll. Hal ini menunjukkan bahwa politik yang dibangun bukan semata-mata berdiri atas dasar masalah bagi kolektivitas kelompok yang mengalami ketidakadilan yang mengandung di dalamnya persoalan pengakuan identitas, tetapi juga kolektivitas berbasis kelas ekonomi dan sosial bersama dengan kelas tertindaslainnya yang memiliki visi bertujuan untuk mengakhiri ketidakadilan kelas (Jamson, 2016).

\section{D.2. Strategi Internal dalam Mengelola Komunitas Waria}

Pembahasan mengenai politik identitas komunitas waria internal merupakan sebuah pergulatan memperebutkan kekuasaan dalam sebuah identitas demi memperoleh legitimasi atas identitas tersebut. Klaim identitas ini terlihat semakin jelas ketika dikaotkan dengan kemampuan individu untuk menempatkan identitasnya pada posisi strategis. Posisi strategis dalam komunitas waria biasanya menjadi perantara antara aktor luar komunitas dengan waria ataupun antara waria dengan waria lain. Tidak semua waria dalam komunitas bisa menempati posisi ini, karena tidak semua waria memiliki modal atau nilai yang dibutuhkan untuk memperoleh kekuasaan.

Widayanti (2009) dalam kacamata Piere Bourdie menyebutkan beberapa modal tersebut, antara lain modal ekonomi yang berbentuk kekayaan; modal kultural seperti pendidikan, ketrampilan; modal sosial berupa jaringan; dan modal simbolis berupa kewibawaan atau kharisma. Di dalam ketiga komunitas waria ini, ada tiga waria yang dianggap memiliki modal tersebut sehingga bisa dikatakan bahwa ketiganya merupakan elit komunitas waria. Mereka adalah Mami Vin (LSM Kebaya), Bu Shinta Ratri (Pondok Pesantren Waria Al-Fattah), dan Bunda Rully (LSM Kebaya).

Selain ketiganya memiliki sapaan yang memiliki arti dihormati, "mami, ibu dan bunda", mereka juga setidaknya memiliki beberapa modal yang mampu memposisikan mereka sebagai elit waria. Dari tingkat pendidikan, baik Bu Shinta maupun Bunda Rully sama-sama merupakan lulusan sarjana. Bu Shinta merupakan alumni Fakultas Biologi Universitas Gadjah Mada (UGM), sedangkan Bunda Rully merupakan lulusan Sekolah Pendidikan Guru di Majene, Sulawesi Barat. Mami Vin juga memiliki modal elit dari kemapanan ekonominya. Saat ini Ia dikontrak oleh Hotel Santika untuk menjadi pemateri kegiatan untuk pengunjung hotel tersebut. Dari sisi modal sosial, ketiganya 
Jurnal Pemikiran Sosiologi Volume 6 No.2 2019

Heteronormativitas, Wacana LGBT dan Perjuangan Komunitas Waria Melawan Stigma

Inestya Kartikaningdryani

mampu membangun jaringan demi kelangsungan komunitas waria.

Sebenarnya, pembentukan identitas sosial komunitas waria juga tidak lepas dari peran elit waria ini. Mereka yang mampu menjadi broker dan mencitrakan identitas waria dalam relasinya dengan aktor lain (Widayanti, 2009). Modal yang dimiliki ketiganya mampu untuk menjadi representasi waria dalam menyuarakan kesetaraan, seperti dalam mengakses pelayanan publik yang tidak diskriminatif. Oleh karena itu, hadirnya ketiga elit waria ini terkesan superior dalam komunitas marginal.

Jamson (2016) menemukan bahwa dengan situasi di Yogyakarta yang kurang ramah bagi kelompok minoritas, ada strategi lain yang menjadi perdebatan internal komunitas tidak hanya di komunitas waria, namun juga di jaringan. Strategi ini dinamai merunduk dan terbuka. Merunduk merupakan strategi untuk mengurangi propaganda dengan don't say, don't talk, tidak membicarakan maupun memprovokasi isu-isu yang ada di kelompok minoritas. Sebaliknya, terbuka merupakan strategi yang memanfaat situasi yang genting untuk mengadvokasi gerakan dan konsolidasi. Justru di situasi genting yang membuka kesempatan mereka untuk menyuarakan ketidakadilan yang dialami.

Strategi inilah yang tidak banyak diketahui waria, sehingga banyak yang tidak berpartisipasi dalam gerakan advokasi. Banyak waria yang belum menyadari situasi saat ini yang bisa dimanfaatkan untuk bersatu melawan ketidakadilan. Ketidaktahuan ini yang memecah komunitas waria menjadi beberapa kubu. Misalnya, ada kubu yang meminta IWAYO melakukan sesuatu dan kubu yang menilai advokasi yang dilakukan IWAYO sudah mengalami kemajuan, terutama dalam mengadvokasi Perda Gepeng.

Identitas juga memainkan peran penting dalam mempertahankan solidaritas dan komitmen anggota kelompok. Banyak kelompok yang terbelah antara menuntut suatu identitas yang jelas dan mendekonstruksi, mengungkapkannya sebagai hal yang tidak stabil, cair dan terkonstruksi (J. Gamson, 1995 dalam Polletta dan Jasper, 2001). Sementara yang lain bisa jadi melihat ketidakstabilan sebuah identitas kolektif sebagai sebuah tujuan yang penting dalam dan dari dirinya sendiri, dengan jejaring di luar kelompok, beberapa memahaminya sebagai sebuah ancaman terhadap kesatuan kelompok atau juga dapat membingungkan publik (Polletta dan Jasper, 2001). Ketidakcocokan suara inilah yang pada akhirnya menyebabkan IWAYO vakum. Padahal jika menilik kembali alasan mengapa mereka membentuk komunitas, sangat disayangkan ketika perjuangan mereka terhenti begitu saja. Perjuangan untuk melawan ketidakadilan memang bukan perjuangan instan, oleh karenanya diperlukan basis kekuatan bersama dari seluruh elemen komunitas.

\section{E. Kesimpulan}

Bagian ini akan menjawab pertanyaan yang sudah disebutkan pada bagian latar belakang; bagaimana waria mengorganisasikan dirinya menjadi komunitas? Bagaimana strategi pengelolaan komunitas waria? 
Jurnal Pemikiran Sosiologi Volume 6 No.2 2019

Heteronormativitas, Wacana LGBT dan Perjuangan Komunitas Waria Melawan Stigma

Inestya Kartikaningdryani

Proses pencarian jati diri seorang waria menjadi dasar pembentukan komunitas waria. Dalam proses pencarian jati diri ini, sebagian besar waria meninggalkan rumah mereka karena menerima kekerasan yang dianggap dapat menyembuhkan mereka. Saat berada di luar rumah, mereka cenderung memilih lingkungan yang sudah ada waria lainnya. Hal ini dikarenakan waria membutuhkan seorang panutan.

Sama halnya dengan ketiga komunitas induk waria, LSM Kebaya, IWAYO dan Pondok Pesantren Waria Al-Fattah. Keberadaan ketiga komunitas ini tidak lepas dari waria panutan karena mereka memiliki modal yang mampu mempresentasikan dirinya berbeda dari waria pada umumnya. Waria panutan ini dapat menjadi penghubung antara pihak internal dan eksternal dalam mengadvokasi perjuangan mereka.

Dinamika sosio-struktural di Yogyakarta mendorong adanya perubahan strategi politik identitas komunitas waria. Pada awal pembentukannya, komunitas waria menekankan identity for education melalui kegiatan-kegiatan yang mendobrak stigma negatif terhadap mereka. Namun, maraknya aksi vigilantisme oleh kelompok intoleran, ditambah perda diskriminatif, membuat komunitas waria menyatukan kekuatan dengan kelompok marginal lainnya. Dengan berjejaring ini, waria lebih berani tampil di publik sehingga mereka menggunakan strategi identity for critique. Hal ini dikarenakan meskipun mereka sudah berjejaring, akses ke pemeirintahan tetap sulit.

Menariknya, perubahan ini tidak disambut hangat oleh seluruh waria di komunitas. Meskipun mereka memiliki kesamaan identitias, tetapi ada perbedaan interpretasi identitias tersebut. Tidak semua waria sadar akan situasi yang sebenarnya. Sehingga, ada beberapa yang memilih untuk bertahan hidup dengan caranya sendiri, ada yang sudah mapan dan tidak ingin mencampuri urusan komunitas. Ditambah, dalam pengamatan penulis yang bisa melakukan strategi identity for critique hanya beberapa waria yang dapat menjembatani urusan ekternal dan internal. Meskipun terpecah menjadi beberapa kubu, waria tetap menjaga komunikasi karena adanya waria panutan tadi. Dalam pandangan penulis, perbedaan pandangan yang terjadi dalam komunitas waria hanya berdampak pada vakumnya IWAYO.

Bagaimanapun juga, dalam penelitian ini penulis masih menemui beberapa hambatan, salah satunya adalah mengenai IWAYO. Struktur kepengurusannya sedang tidak aktif, sementara pengurus intinya aktif di komunitas lain. Terlepas dari hal tersebut, pergerakan waria hingga hari ini mampu membawa perubahan. Misalnya, razia terhadap waria sudah mulai berkurang dan mereka sudah memiliki keberanian untuk melawan ketidakadilan dengan adanya jaringan yang lebih besar. 
Jurnal Pemikiran Sosiologi Volume 6 No.2 2019

Heteronormativitas, Wacana LGBT dan Perjuangan Komunitas Waria Melawan Stigma

Inestya Kartikaningdryani

\section{Daftar Pustaka}

Ahnaf, Mohammad Iqbal dan Salim, Hairus. 2017. Krisis Keistimewaan, Kekerasan terhadap Minoritas di Yogyakarta. CRCS UGM: Yogyakarta.

Alimi, M. Y. 2004. Dekonstruksi Seksualitas Poskolonial: Dari Wacana Bangsa Hingga Wacana Agama. LkiS: Yogyakarta.

Alimi, Moh. Yasir. 2013. Judith Butler: Gender dan Seks sebagai Pertunjukan dalam Manusia, Perempuan dan Laki-laki, Pareanom, Yusi Avianto. Salihara: Jakarta.

Bernstein, Mary. 1997. Celebration and Suppression: The Strategic Uses of Identity by the Lesbian and Gay Movement. American Journal of Sociology, Vol. 103 (3): 531-565.

Boellstorff, T. 2004. Playing Back the Nation: Waria, Indonesian Transvestites. Cultural Anthropology, Vol. 19 (2): 159-195.

Brunt, Lodewijk. 2001. Into the Community dalam Handbook of Etnography, P. Atkinson, dkk (Eds). SAGE Publications: London, California, New Delhi, Singapore.

Candraningrum, Dewi. 2013. Negotiating Womens Veiling, Politics and Sexuality in Contemporary Indonesia. IRASEC: Bangkok.

Garber, Judith. 2012. Defining Feminist Community, Place, Choice and the Urban Politics of Difference dalam The Community Development Reader, DeFilippis, James and Seagert, Susan. Routledge: New York and London.

Jamson, Ulya Niami E. 2016. Tranformasi Strategi Gerakan Waria Yogyakarta: Politik Redistribusi dan Politik Rekognisi Untuk
Keadilan Sosial. Tesis. Program Pascasarjana Departemen Politik dan Pemerintahan, FISIPOL, UGM

Kugle, Scott Siraj al-Haqq. 2014. Living Out Islam, Voices of Gay, Lesbian and Transgender Muslims. New York Press: New York

Kyle, Knight. 2016. Permainan Politik ini Menghancurkan Hidup Kami, Kelompok LGBT Indonesia dalam Ancaman. Human Rights Watch: Amerika Serikat.

Laazulva, I. 2013. Menguak Stigma, Diskriminas dan Kekerasan pada LGBT di Indonesia. Arus Pelangi: Jakarta.

Oetomo, D dan K. Suvianita. 2013. Laporan LGBT Nasional Indonesia- Hidup Sebagai LGBT di Asia. Bali.

Polleta, Fransesca; Jasper, James. 2001. Collective Identity in Social Movements. Annual Review of Sociology, Vol. 27 (1): 283-305.

Saputra, Pepri. 2016. Perjuangan Politik Identitas Hangudi Bawanatata Lahir Batin dalam Merebut Hak Sipil. Skripsi. Departemen Politik Pemerintahan, FISIPOL UGM.

Setyorini, A. 2011. Performativitas Gender dan Seksualitas dalam Weblog Lesbian di Indonesia. Kawisatara, Vol. 1 (2): 103-212.

Stall, Susan dan Stoecker, Randy. 2012. Community Organizing or Organizing Community? Gender and the Craft of Empowerment dalam The Community Development Reader, DeFilippis, James and Seagert, Susan. Routledge: New York and London.

Skeggs, Beverley. 2001. Feminist Etnography dalam Handbook of Etnography, P. Atkinson, dkk (Eds), SAGE Publications: London, California, New Delhi, Singapore. 
Jurnal Pemikiran Sosiologi Volume 6 No.2 2019

Heteronormativitas, Wacana LGBT dan Perjuangan Komunitas Waria Melawan Stigma

Inestya Kartikaningdryani

Widayanti, Titik. 2009. Politik Subaltern, Pergulatan Identitas Waria. Research Center for Politics and Government. Jurusan Politik Pemerintahan, UGM: Yogyakarta.

Sumber Lain (Internet):

Azis, Abdul, 2016, SGRC UI Accused of Being LGBT Community, Tempo, 24 Januari 2016 (https://nasional.tempo.co/read/738938/s grc-ui-accused-of-being-lgbt-community/) Diakses 12 April 2017.

Batubara, Herianto, 2016, Menristek: Saya Larang LGBT di Semua Kampus, Itu Tidak Sesuai Nilai Kesusilaan, Detiknews, 24 Januari 2017 (https://news.detik.com/berita/3125654/ menristek-saya-larang-lgbt-di-semuakampus-itu-tak-sesuai-nilai-kesusilaan/) Diakses 12 April 2017.

Fauzi, Gilang, 2016, SGRC UI Tegaskan Diri Grup Konseling, Bukan Komunitas LGBT, CNN Indonesia, $25 \quad$ Januari 2016 (https://www.cnnindonesia.com/nasional/ 20160125112353-20-106441/sgrc-uitegaskan-diri-grup-konseling-bukankomunitas-lgbt/) Diakses 11 April 2017.

Fikrie, Muhammad, 2016, Kelompok Pro dan Anti LGBT Nyaris Bentrok di Yogyakarta, Beritagar.id, 23 Februari 2016 (https://beritagar.id/artikel/berita/kelomp ok-pro-dan-anti-lgbt-nyaris-bentrok-diyogyakarta/) Diakses 9 September 2017.

Firdaus, Febriana, 2016, Pesantren Waria di Yogyakarta ditutup Sementara, Rappler, 25 Februari 2016 (http://www.rappler.com/indonesia/1236 65-ponpes-waria-yogyakarta-resmiditutup). Diakses 11 April 2017.

Sucipto, 2017, Menhan Tegaskan LGBT Menjijikan, Tak Sesuai Pancasila, Sindonews, 24 Mei 2017 (https://nasional.sindonews.com/rea d/1207684/15/menhan-tegaskan-lgbtmenjijikan-tak-sesuai-pancasila1495600544/). Diakses 1 September 2017. 